This item is the archived peer-reviewed author-version of:

A peculiar enterprise : the fate of metaphysics in a naturalist climate

\title{
Reference:
}

Meijer Michiel.- A peculiar enterprise : the fate of metaphysics in a naturalist climate

International journal of philosophy and theology - ISSN 2169-2327 - 79:1-2(2018), p. 1-17

Full text (Publisher's DOI): https://doi.org/10.1080/21692327.2017.1402691

To cite this reference: https://hdl.handle.net/10067/1475640151162165141 


\title{
Citation Info
}

When citing this text, please refer to the original publication:

\author{
Meijer, Michiel, 2017, "A Peculiar Enterprise. The Fate of Metaphysics in a Naturalist \\ Climate", International Journal of Philosophy and Theology, online first (winner of \\ 2017 International Journal of Philosophy and Theology Essay Prize)
}

\section{A Peculiar Enterprise The Fate of Metaphysics in a Naturalist Climate}

\author{
Michiel Meijer (University of Antwerp)
}

\begin{abstract}
In this paper, I examine the divide between 'analytic' and 'continental' approaches to metaphysics by reconstructing a three-cornered debate between naturalists, hermeneutists, and pragmatists on the issue of how to understand the relationship between ethics and ontology. Taking my cue from the dominant naturalistic debates in Anglo-American ethics, I continue to discuss in more detail the positions of Hilary Putnam and Charles Taylor in the light of these debates. More particularly, I investigate Putnam's wholesale rejection of (what he calls) Ontology with a capital 'O', while also exploring Taylor's retrieval of ontological thinking for (what he calls) Ethics with a capital ' $E$ '. Drawing attention to the deep metaphysical uncertainties in all of these approaches, I ultimately seek to develop a well-defined perspective from which to evaluate the peculiar status of metaphysics in contemporary philosophy, reflecting on its fate beyond the analytic-continental split.
\end{abstract}

Keywords: Metaphysics, ontology, ethics, naturalism, hermeneutics, pragmatism, Putnam, Taylor

What are the ontological commitments behind our ethical views? Many philosophers are inclined to answer 'none'; moral and factual beliefs are in different spheres. Metaphysical and ontological discussions - discussions about what exists and the nature of reality - have long been among the most researched debates in philosophy. ${ }^{1}$ However, the many different approaches to ontology have grown so far apart over the last few decades that it has become highly debatable whether 'ontology' still designates a single philosophical domain. For this very reason, many argue that ontological debates are non-substantive, pointless or incoherent, thereby accepting that there is no objectively best language that accurately describes the structural features of reality. Within this climate, the very attempt to articulate the relationship between ethics and ontology is often contested. This predicament raises a crucial question: Does the peculiar status of metaphysics also demand the exclusion of ontological theorizing from ethics?

The philosophical reflection on this question is often divided into two camps: 'analytic' philosophy and 'continental' philosophy. Although neither analytic nor continental 
philosophy is an organized philosophical program or a unified philosophical tradition, the analytic-continental distinction still operates ideologically and normatively as it is often used to approve (and disapprove) philosophical projects and proposals and to recommend (and rebuke) philosophical sources and research materials. Yet it has proven difficult to specify accurately the difference between these alternative orientations. One way to draw the distinction is to contrast the discourse of two cultural worlds, one 'scientific' and the other 'humanistic.' ${ }^{2}$ Another is to begin from the observation that there is 'a gap in much philosophy between theoretical questions about how one knows what one knows, and more practical or existential questions of what it might mean to lead a good or fulfilled human life.' ${ }^{3}$ A third way is to stress the different types of criteria in analytical and continental approaches. Analytic philosophy would then be characterized as 'systematic' and 'argumentative', praised for its 'exactitude, consistency, and veracity' in building on the model of science; whereas continental philosophy would be described as 'radical' in the pursuit of 'extremeness, depth, and creativity', goals that are closer to poetry and religion than to science. ${ }^{4}$

As these characterizations indicate, the analytic-continental divide is best understood as a dispute between the scientific conception and reconstruction of the world advanced by the former and the existential experience and interpretation of the world explored by the latter. However, some areas of philosophy, and the philosophers reflecting on them, seem to be excluded by the analytic-continental dichotomy. The works of authors such as Bernard Williams, Richard Rorty, Hilary Putnam, Charles Taylor, Hubert Dreyfus, and John McDowell all move beyond this divide by having characteristics of both traditions. Yet it is precisely because their writings contain elements that both the analytic and the continental traditions can recognize that their views provide a unique lens through which to examine the analytic-continental split. In this way, we can ask whether some of these authors provide a kind of 'bridge' between the two camps, or whether their views represent a unique option, irreducible and perhaps even superior to either side.

Against this background, the central objective of this paper is to unravel the very opposition between analytic and continental philosophy by exploring a more specific and informative characterization of the felt separation in terms of a three-cornered battle between 'naturalists', 'hermeneutists', and 'pragmatists'. I argue that once this characterization is made, we immediately get a clear sense of a deep divide between conflicting philosophical views on the significance of metaphysical explanations for understanding morality. That is, we easily recognize 'naturalistic' doctrines that take empirical science as our best guide to understanding reality - including ethics (in the spirit of Carnap and the logical positivists, thinkers such as Ayer, Mackie, Quine, and, more recently, Blackburn, Jackson, and Railton all defend different brands of ethical naturalism). Yet we can also identify 'hermeneutical' theories, which argue that meaningful human action is an interpretative issue more than anything else, and that, therefore, the empirical sciences do not provide human beings with their most significant access to the world (exemplified in the writings of Husserl, Dilthey, Heidegger, and, more recently, Gadamer, Ricoeur, and Taylor). And we recognize 'pragmatic' views that insist neither on empirical science nor on theories of meaning but on practical 
consequences for settling philosophical disputes (pioneered by Peirce, James, and Dewey, and further developed in our day by Rorty, Putnam, and Brandom).

With these points in place, the threefold aim of this paper is, first, to illuminate the analytic-continental divide in terms of the debate between naturalists, hermeneutists, and pragmatists; second, to narrow down the focus of this debate by concentrating on the relationship between ethics and ontology; and, third, to show how ontological uncertainties arise in naturalistic, hermeneutical, and pragmatic approaches alike by examining what is perhaps best described as the 'post-analytic-continental' positions of Hilary Putnam and Charles Taylor. In this way, I ultimately seek to develop a well-defined perspective from which to evaluate the peculiar status of metaphysics in contemporary philosophy, reflecting on its 'fate' beyond the analytic-continental split.

This paper is divided in five sections. In the first section, I introduce the unusual positions of Putnam and Taylor against the background of the dominant naturalistic debates in AngloAmerican ethics. I then examine their pragmatic and hermeneutical views in more detail in the second and third sections, first, by discussing Putnam's wholesale rejection of ontology in Ethics Without Ontology, ${ }^{5}$ and, second, by reconstructing Taylor's tentative retrieval of ontological thinking in the papers 'Ontology' and 'Ethics and Ontology'. ${ }^{6}$ In the fourth section, I continue to highlight the deep metaphysical uncertainties in Taylor's Retrieving Realism. ${ }^{7}$ Based on these discussions, I finally conclude in the fifth section with a proposal that might help to overcome these uncertainties.

\section{Naturalism: The Only Game in Town?}

Putnam's philosophy is generally situated in the tradition of pragmatism. Like the analytic and continental traditions, pragmatism developed around the turn of the 20th century. Although classical pragmatists such as Charles Sanders Peirce, William James, and John Dewey influenced (and were influenced by) the founding thinkers on both sides of the divide, the most influential forms of contemporary pragmatism have developed largely in analytic philosophy, exemplified by the views of Rorty and Putnam. However, the classification of Putnam as an analytic philosopher seems somewhat of an uneasy fit because it overlooks his ongoing critique of the naturalist trend within Anglo-American ethics. Indeed, by presenting himself as a 'naturalist in John Dewey's sense', ${ }^{8}$ Putnam has been arguing from the outset that moral features simply disappear by adopting a scientific stance in general and by making the fact-value distinction a criterion of ethics in particular. Yet it was only recently that he saw that, in order to reach a correct moral realistic position, the main enemy to overthrow was Ontology with a capital ' $\mathrm{O}$ '. ${ }^{9}$ Arguing that the Quinean revival of ontology over the past few decades has had 'disastrous consequences for just about every part of analytic philosophy', Putnam's latest project was to criticize 'the whole idea of Ontology'; indeed, to 'pronounce an obituary' on it. ${ }^{10}$

Taylor, like Putnam, has been debunking naturalism in the human sciences since well before its recent popularity in philosophical ethics. For Taylor, however, challenging naturalism requires not pragmatic considerations but a distinctive hermeneutical perspective that connects ethical and ontological reflections rather than to separate them. Making room 
for what he recently described in The Language Animal as 'the package of Ethics' in the broad sense - indeed, the capital letter here is intentional as well - his view is that explaining human actions and responses requires not only 'identifying their causes' but also 'making the actions/responses understandable'. ${ }^{11}$ In developing this view, Taylor makes it clear that his position obviously appeals to 'the tradition of empathetic understanding (Verstehen) invoked for human sciences since Wilhelm Dilthey', and pursued by figures such as Weber, Heidegger, Gadamer, and Ricoeur. ${ }^{12}$

Taylor's hermeneutical perspective is usually included in the category of continental philosophy, and thus it is often contrasted with the naturalistically inspired analytical debates in which Putnam takes center stage. Yet this way of putting the matter is misleading. For one thing, it overlooks that Taylor makes a rather unusual continental philosopher, not only because he was brought up with the analytical models of linguistic philosophy that flourished at Oxford in the fifties, but also because his distinctive hermeneutics steers a course between Murdochean ethics, Kantian epistemology, Merleau-Pontyan phenomenology, and Heideggerian ontology. This makes Taylor rather difficult to class.

On the whole, although rooted in philosophical traditions that are often seen as mutually exclusive, Putnam and Taylor have engaged in such wide-ranging discussions that their metaphilosophical reflections have resonances within analytical and continental discussions alike. Hence my label of their views as 'post-analytic-continental'. It is clear, however, that Putnam and Taylor have a shared philosophical agenda, namely, to show that there is something deeply wrong with naturalistic approaches to value.

To make this point, they equally define moral knowledge as autonomous and discontinuous with non-moral knowledge, resulting in intricate epistemological and ontological arguments which claim that moral truths - that is, those that do not 'fit' into the world picture of science - do not need empirical evidence to be justified. Yet the assumed alliance between Putnam and Taylor becomes more complex when considering, first, that they scarcely refer to each other's arguments, and, second, that the analytic debates with which Putnam engages generally have no room for a hermeneutical perspective such as Taylor's. At the same time, though, many naturalistically oriented philosophers within these debates find themselves in agreement with Taylor to the extent that they also seek to defend the autonomy of morality in the face of empirically informed reductions of the moral. They seek to do so either by arguing that morality is in some fundamental sense different from natural, empirically observable entities (Shafer-Landau, Wedgwood, Enoch, Parfit), or by arguing for broader, non-reductive types of naturalism (McDowell, Putnam, Rorty, Hornsby).

Yet despite the tendency towards non-reductivism in Anglo-American ethics, the metaphilosophical assumptions underlying the debate concerning the relationship between ethics and ontology have remained naturalist. As a result, the defense of the autonomy of morality is now almost exclusively articulated from a naturalistic standpoint to the extent that the central question is this: How can morality fit in the natural world? The thrust of this debate is well described by Simon Blackburn, who argues that the central problem of contemporary ethics is one of 'finding room for ethics, or placing ethics within the disenchanted, non-ethical order which we inhabit'. ${ }^{13}$ 
From this perspective, the tasks of moral philosophy are, first, to assume the methodological superiority of the empirical sciences, and, second, to develop forms of ethics and ontology that can be aligned with the scientific worldview. In this way, it is generally accepted that philosophical explanations of morality must be compatible with the view that our scientific understanding is the best story we now have about reality. Thus the problems of non-reductive naturalism arise: Where do moral properties (such as goodness and rightness) fit within such a reality, and how are we able to learn about them? These ontological and epistemological burdens continue to be subjects of intense debate in contemporary metaethics. However, the unexamined presupposition behind these burdens is that a reasonable form of ethics must be elaborated from a naturalistic perspective. Moreover, the implicit conclusion that facts and values lie in different domains requires the additional assumption that ethical statements are not really 'factual'. This begs all the crucial questions about the relationship between ethics and ontology.

So while non-reductivism is gaining ground in contemporary ethics, naturalism still seems to have won the all-important methodological war by dictating how metaethical questions should be addressed, namely by developing arguments that can be aligned with empirical science. In this regard, naturalism has indeed become 'the only game in town'. ${ }^{14}$ Against this background, what is striking about the philosophies of Putnam and Taylor is that they reject the very framework in which the above discussions take place. Putnam explains his position:

Today we tend to be too realistic about physics and too subjectivistic about ethics, and these are connected tendencies. It is because we are too realistic about physics, because we see physics (or some hypothetical future physics) as the One True Theory, and not simply as a rationally acceptable description suited for certain problems and purposes, that we tend to be subjectivistic about descriptions we cannot 'reduce' to physics. Becoming less realistic about physics and becoming less subjectivistic about ethics are likewise connected. ${ }^{15}$

Similarly, Taylor sees a growing 'naturalist temper' not just in the outlooks of 'many students of the sciences of human behavior' but in our culture as such, 'stopping short frequently of explicit espousal of full-blooded naturalism, but tending to be suspicious of the things that naturalism cannot accommodate'. ${ }^{16}$ Although Putnam and Taylor recognize that 'naturalism' is far from a straightforward position, their methods involve not so much detailed engagements with naturalist moral theories as the defense of a pragmatist or hermeneutical counterposition that rejects any appeal to scientism in ethics, understood as the application of scientific procedures to areas of our lives in which these procedures do not belong. In this way, Putnam criticizes a 'scientistic' understanding of naturalism for neglecting 'the ways of thinking that are indispensable in everyday life', ${ }^{17}$ while Taylor attacks the view that sees human action as 'ultimately explicable in terms that are consonant with modern natural science'. ${ }^{18}$ Put simply, their shared concern over naturalism is that science should not overreach its purview: the scientific approach is legitimate within the boundaries of empirical inquiry, but should not enter into other areas - in particular, ethics - where different standards and criteria apply. 
Given these points, it is worth noting that Putnam and Taylor, while they are quite convinced that naturalistic theories are on the wrong track, both lack a clear vision on how to explain the metaphysical status of our values. As will emerge, Putnam criticizes not just naturalism but any ontological approach to ethics as obsolete, yet he remains silent about the implicit ontological claims that substantiate this critique. Taylor, then, is quick to reject any naturalist approach for understanding ethics and ontology but struggles to articulate a more fitting metaphysics for himself. I will elaborate on this in the following sections.

\section{Ontology With a Capital ' $O$ '}

In Ethics Without Ontology, Putnam continues to defend moral objectivity and the fact/value entanglement - as explained in more detail in The Collapse of the Fact/Value Dichotomy but now adds that the attempt to provide an ontological explanation of the objectivity of ethics is 'deeply misguided'. ${ }^{19}$ In so doing, Putnam endorses what he calls 'pragmatic pluralism', a view that combines a pragmatic conception of ethics as concerned with 'the solution of practical problems' with a pluralist take on ordinary language as involving 'many different kinds of discourses,' that is, 'different "language games" in Wittgenstein's sense'. ${ }^{20}$

Putnam's pragmatic pluralism then feeds into an anti-metaphysics when he explicitly rejects the attempt to provide ontological explanations in ethics as 'an attempt to provide reasons which are not part of ethics for the truth of ethical statements' ${ }^{21}$ By contrast, Putnam explains, the major advantage of his own non-ontological proposal is that it 'does not require us to find mysterious and supersensible objects behind our language games' as 'the truth can be told in language games that we actually play when language is working' ${ }^{22}$ From this perspective, any explanation of moral statements in terms that reach beyond the practices in which these statements occur is ultimately superfluous. In this sense, 'metaphysics is almost by definition contrary to common sense' ${ }^{23}$

The most significant innovation of Ethics Without Ontology is perhaps the way in which Putnam connects a pragmatic-pluralist reconstruction of moral objectivity with a wholesale rejection of ontological modes of thinking. Yet while Ontology as such - note the capital ' $\mathrm{O}$ ' - is said to be at the core of Putnam's critique, his main targets are 'inflationary' metaphysical realism, on the one hand, and 'deflationary' reductive naturalism, on the other. ${ }^{24}$ What is wrong with inflationary (Platonic) metaphysics is that 'by postulating something "non-natural", something mysterious and sublime standing invisibly behind the goodness of the persons, actions, situations, etc., in question', one thereby reduces all ethical phenomena to 'just one issue, the presence or absence of this single super-thing Good' ${ }^{25}$ Conversely and yet similarly, the problem with deflationary forms of ontology is that they either reduce or eliminate altogether the diversity of ethical questions and value problems. In this way, Putnam criticizes 'reductionist' deflationary views for claiming such questions and problems to be 'nothing but' something else, for example, by arguing that 'goodness is nothing but pleasure' or 'properties are nothing but names' or 'ethical utterances are nothing but expressions of feeling'. ${ }^{26}$ Additionally, he also refutes the closely related 'eliminationist' deflationist view that aims to show us not, like the reductionist, what we are 'really' saying in ordinary moral language, but that we are in fact 'talking about mythical entities' ${ }^{27}$ 
It would seem, therefore, that both inflationary and deflationary modes of metaphysics fall prey to what Putnam calls 'the illusion that there could be just one sort of language game which could be sufficient for the description of all of reality ${ }^{28}$ - thereby glossing over the fact that the world can be correctly described from a number of different perspectives. In this regard, Tiercelin notes that the more Putnam moved to his pragmatic pluralism, the more he realized that 'metaphysical realism was not the only foe, but that we should free ourselves from any kind of metaphysical temptation' ${ }^{29}$ Surprisingly perhaps, Putnam stresses that it is in analytic philosophy in particular that Ontology (in both of its main forms) flourishes. He argues:

We have just seen that ontology was made respectable, in analytic philosophy, by Quine's idea that you could read it off of the existential commitments of your theory, which he thought was the unified scientific theory of everything. But we have also seen that if you leave Quine's scientism to one side, you will realize that we don't have a single, unified theory of the world off of which to read our ontology. ${ }^{30}$

Yet Putnam's critique of analytic metaphysics is so sweeping that it leads him to get rid of all ontologizing, abandoning the very idea of ontology. As he puts it in his concluding 'obituary':

I promised an obituary on Ontology, but to extend these remarks would not be so much an obituary as flogging a dead horse. Instead, I shall just say this (since it is customary to say at least one good word about the dead): even if Ontology has become a stinking corpse, in Plato and Aristotle it represented the vehicle for conveying many genuine philosophical insights. The insights still preoccupy all of us in philosophy who have any historical sense at all. But the vehicle has long since outlived its usefulness. ${ }^{31}$

Although a lot more could be said on this, for present purposes it suffices to note that our current metaphysical predicament, as Putnam understands it, allows only two ontological positions: inflationary Platonism, on the one hand, and deflationary naturalism, on the other. From here is it only a small step, Putnam argues, to the conclusion that a non-ontological position is in fact the only plausible alternative after the collapse of these views.

However, although Putnam's talk of 'mysterious,' 'invisible,' and 'supersensible' objects in refuting inflationary metaphysics might help to ridicule the notion of ontology, this tactic does nothing to show that ethical and ontological commitments are unconnected. In this respect, Putnam seems to ignore the reality that most contemporary metaphysical debates do not have principally to do with Platonic forms or abstract entities. Moreover, simply replacing ontological questions with pragmatic concerns does not make ontological questions go away. It therefore remains doubtful whether, say, the appeal of strong values such as universal respect and benevolence can be fully explained only in terms of their use for the solution of practical problems, or that ethics in general is such a narrow domain as Putnam tends to reduce it to. 
This leaves us with Putnam's rejection of deflationary naturalism. Here he is surely entirely right to point out that it is dangerously scientistic to regard empirical science as being more closely in touch with the structure of reality than other explanatory languages. Yet the force of this argument is rather limited as it rules out only a reductive scientistic conception of ontology. Towards the end of his obituary, however, Putnam clarifies that this is no small feat as his argument - broadly addressed to scientism, then also more particularly to Quine, Williams, Blackburn, and Churchland - draws attention to a widely supported 'metaphysical reason' to deny the objectivity of ethical judgment, namely 'that it doesn't fit the picture of "description of natural facts". 32

This means that Putnam's ultimate target (or so we learn at the end of his analysis) is neither Platonism nor ontologizing as such, but the dominant scientism in analytic philosophy. In other words, after the demise of inflationary metaphysics, Putnam sees only two positions left for us to adopt: either the pragmatist view that he defends or the neo-Quinean outlook that has been the predominant approach to ontology over the past half-century, that is, the view that it is 'only our best scientific theory of the world that says anything we can take seriously about what there is' ${ }^{33}$ The problem with the latter, then, is that although human beings are inevitably part of nature as studied by empirical science, no theory has hitherto been able to clarify the full breadth of our ethical deliberations exclusively in empirical terms.

To clarify this point, Putnam stresses that we generally do not think that a statement such as 'Some passages in Kant's writing are difficult to interpret' needs to be replaced by a scientific explanation. ${ }^{34}$ However, he continues, this commonsense view puts the advocates of naturalism in a rather peculiar metaphysical position. As Putnam argues:

So the statement about Kant isn't part of our best scientific theory of the world - it isn't part of any 'theory'. Are you really prepared to conclude with Paul Churchland that passages which are difficult to interpret do not exist? That believing that there are passages which are difficult to interpret is like believing an outmoded scientific theory, like believing in phlogiston, caloric, and the four elements of medieval alchemy? Isn't there something mad about such a conclusion? Or should we conclude with Bernard Williams that such beliefs are only true 'relative to some social world or other', whatever that means? Or should we be 'quasi-realists' about them with Simon Blackburn? How high the seas of language run! $!^{35}$

Although these points are well taken, Putnam's critique would have been far more penetrating if he had also allowed some conceptual space to articulate the metaphysical commitments of his own pragmatist proposal. Yet this is precisely what his position cannot do - in fact, refuses to do. In this respect, it is crucial that Putnam not simply eschews an elaboration of his rather one-dimensional picture of ethics as merely concerned with practical problems, but that it lies in the very nature of his rigorous anti-metaphysical approach to keep its most basic assumptions inarticulate, that is, assumptions about what we need to commit ourselves to in our experience of and acting in the world.

It should not surprise us, then, that there is little doubt among Putnam's commentators that this deliberate inarticulateness is the Achilles heel of Putnam's position. Pihlström, for example, criticizes Putnam for leaving it unsettlingly unclear whether 'pragmatism is, or can 
be reinterpreted as, an ontologically relevant framework.${ }^{36}$ Copp concurs when he says, first, that Putnam has failed to give 'blockbuster arguments against Ontologizing as such,' and, second, that Putnam himself "engages in ontologizing that at least bears a close family resemblance to Ontologizing ${ }^{37}$ In line with this, Tiercelin argues in reference to Peirce that 'any project of getting rid of all metaphysics is from the start doomed to failure, since "everyman of us has a metaphysics", and "becomes more or less imbued with philosophical opinions, without being clearly aware of it"'.38

These points show that Putnam ultimately presents us with a false dilemma by explaining our metaphysical predicament as one between his non-ontological pragmatism and ontological naturalism. What is missing in this dichotomy is precisely the idea that there is such a thing as the best metaphysical explanation beyond the naturalist deadlock that makes sense of our values in a way that neither 'inflates' nor 'deflates' them. What is missing, or so I argue in the next section, is the possibility of an ontological view like Taylor's.

\section{Ethics With a Capital ' $E$ '}

Throughout the course of his writing, Taylor continuously raises the question of what we are committed to ontologically by our ethical views, but there is always something tentative in his adhesion. A large part of the problem could well be that his first engagement with ontology in the paper 'Ontology' ends in a state of aporia, where Taylor finds himself forced to conclude that ontological questions are both 'unavoidable' and 'unanswerable'. ${ }^{39}$ Showing admirable consistency, this paper already prepares the way for both Taylor's 'pluralistic robust realism' in Retrieving Realism and his latest hermeneutical defense of 'Ethics in the broad sense' in The Language Animal. ${ }^{40}$ In developing these views, he implicitly mirrors Putnam's effort of extending the relevance of pluralism from scientific examples to the domain of ethics. In so doing, however, Taylor employs a completely different conception of ethics from Putnam by arguing that moral language introduces certain 'metabiological meanings' in our world, which invoke issues of 'strong evaluation' or 'strong value', that is, 'value independent of our recognition'. ${ }^{41}$ He explains:

This exists where what is valued comes across to us as not depending on our desires or decisions, or on whether or not we grasp it; rather the valued reality comes across as such that our not appreciating it, far from undermining its value, would on the contrary reflect negatively on our ability to perceive it. ${ }^{42}$

Labeling this view as Ethics with a capital ' $E$ ' - which includes principles of obligatory action as well as a sense of the virtues and motivations that define the good life for us ${ }^{43}-$ Taylor continues to argue, against Putnam's 'ethics without ontology', that ontology must be retained within this broader definition of Ethics.

As noted, Taylor's latest position can be traced back to his (largely neglected) early paper 'Ontology'. This paper centers on the following question: How does the ontology of human behavior, expressed in ordinary language, relate to the ontology of natural processes and material objects, expressed in terms of science? In Taylor's view, difficulties start to emerge when considering that everyday language involves 'behavior by sentient beings', 
which, in being endowed with meaning, differs from movements of material objects or natural processes. ${ }^{44}$ That is, for behavior to be meaningfully recognized as, say, 'insolent', we must be presupposing a background that is somehow different from an ontology that recognizes only 'natural' processes devoid of such meanings. Children can be insolent, molecules cannot. ${ }^{45}$

Taylor sees this problem as 'unavoidable' in the sense that human beings can be adequately described by a plurality of explanations; in this case, by both ordinary, commonsense terms (insolent, obedient, hostile, friendly) and by scientific, objectifying languages (biological, physiological, psychological, psychiatrical) ${ }^{46} \mathrm{He}$ continues to identify this problem as 'ontological' rather than 'linguistic' because some of our descriptions "presuppose a "world" in which the things and happenings we speak about in the other strata cannot find a place'; put simply, 'our ontological commitments clash' ${ }^{47}$ As we will see later on, this problem - that some ontological commitments are in conflict with others - is at the root of Taylor's more recent question about the relationship between the different languages by which we describe and understand ourselves. For the young Taylor, then, this problem generally emerges from the impact of scientific explanations of our world. As he says:

The problems are posed by the advance of science, or at least by a greater awareness of the nature of the world around us. Once we begin to talk about nature in terms that are not animistic, we begin to wonder about persons, for they, after all, are parts of nature, are material objects also. But we want to say that they are something 'more' as well. ${ }^{48}$

From this perspective, the issue is not whether we can talk meaningfully about human behavior in ordinary language, but, given our faith in science and scientific terminology, how ordinary language differs from, and is related to, events and processes in nature. Although the young Taylor admits to being 'perplexed' by this problem, he has no doubts about how not to deal with the 'ontological gaps' in our language: by trying to assimilate ordinary language terms to scientific statements and concepts. ${ }^{49}$ He argues:

The world of physics and the world of everyday, the psyche of psychoanalysts and the mind of ordinary speech, these parts and others will not converge into single images. Our logical focus is askew. The problems that arise are philosopher's questions, but the experience of perplexity is not confined to philosophers. In particular, it is philosophers who take this as the starting point of metaphysical systems, but they are not alone in giving credence to them. [...] In a sense, the questions we ask in this domain are unanswerable. But they are not, for all that, imaginary questions. ${ }^{50}$

Before considering how the later Taylor gradually develops this mode of reasoning into a critique of naturalistic moral theories, it is important to realize that his debut in ontology - an attempt to show that ontological questions are both unavoidable and unanswerable - sets a rather tricky stage for the further development of his thought. As the young Taylor concludes, 'our metaphysical craving for the real language remains unsatiated'. ${ }^{5}$

In the paper 'Ethics and Ontology', Taylor continues and extends his original discussion of 'Ontology' by attacking the naturalist view that sees human action as 
'ultimately explicable in terms that are consonant with modern natural science' ${ }^{52}$ Refuting this approach, he argues that our moral culture sets us the following challenge: either we correct our naturalist ontology or we must revise the most salient features of our moral experience. That is, in Taylor's view, there is a clear lack of fit - or, recalling his old terminology, an ontological 'gap' - between our moral experience, on the one hand, and 'the ontology we allow ourselves as post-Galilean naturalists', on the other. ${ }^{53}$

To clarify this tension, he stresses that the attribution of value is fundamentally different from attributing so-called 'secondary' qualities, such as color, in that 'questions of merit now arise'. ${ }^{44}$ That is, we can be asked to demonstrate the 'rational grounds' of a normative statement such as 'you are dishonest' in a way that we would never be asked to show that the table is really red. ${ }^{55}$ The problem for ethical naturalism, then, is precisely to account for this 'qualitative status of the ethical' that defines our sense of morality; that is, the sense that moral values are 'in some way special, higher, or incommensurable with our other goals and desires'. ${ }^{56}$ Taylor then presents his moral phenomenology as a problem for naturalist ontology:

There is a tension between phenomenology and ontology. The former, properly and honestly carried through, seems to show that values of this higher status [...] are ineradicable from our deliberations of how to live. But ontology, defined naturalistically, says that properties of this kind can have no place in an account of things in the world..$^{57}$

Although Taylor thus strategically develops his moral phenomenology as a full-out attack on naturalist-inspired metaphysics, what is most striking about his analysis is that its results are fundamentally inconclusive. Starting his discussion from the views of Mackie and Blackburn, who seek to resolve the tension by 'resisting the phenomenology', via McDowell's alternative resolution to 'challenge the ontology' instead, Taylor ultimately has to conclude that 'the hoped-for reconciliation between moral phenomenology and naturalist ontology is, to say the least, somewhat premature'. ${ }^{5}$

At the same time, however, he continues to heighten the tension by insisting that we must suffer either the pain of 'resisting the phenomenology' or the pain of 'challenging the ontology'. For Taylor, the difficulty with naturalistic views such as Mackie's and Blackburn's is that they boldly decide beforehand that everything in nature is to be explained in terms of post-Galilean science, without even formulating it as a basic assumption - let alone arguing for it - and only then conclude that values cannot but appear as 'queer' or 'quasi'-real entities. ${ }^{59}$ Rejecting this tactic, Taylor ultimately urges us to consider that the only real option left is to challenge naturalist ontology.

Unfortunately, though, these points do not explain how we should respond to the problem with which the young Taylor started, that is, the deeply metaphysical problem that the ontological commitments of our different languages not simply clash but exclude one another at times. In this regard, it is most revealing of Taylor's uncertainty that the very paper in which he puts the connection between ethics and ontology forward as a central theme breaks off with the comment that his thoughts on this topic are "still too crude to explore this in an illuminating fashion'. ${ }^{60}$ 


\section{Robust Realist Uncertainties}

More needs to be said on this, because Taylor will have to be honest about his own metaphysical view in criticizing naturalist ontology, for this cannot be rejected without reaching out to some ontological contraposition. In this respect, simply having recourse to moral phenomenology is as if a category Taylor needs for his metaphysical urges is being illegitimately credited with a phenomenological grounding. Anticipating this critique, he makes one last effort in Retrieving Realism to salvage conflicting ontological commitments.

He does so by separating what he calls 'life meanings, which we share as biological creatures' from 'human meanings,' that is, 'meanings on a moral, or an ethical, or a spiritual level, having to do with what are seen as the highest goals or the best way of life' ${ }^{61}$ Against the background of this distinction, Taylor continues to argue that the naturalist attempt to reduce human meanings to basic life meanings in an all-inclusive scientific theory seems an 'unpromising strategy' since 'the basis of our science is the discovery of a universe whose causal laws take no account of us and our human meanings' ${ }^{62}$ By making this point, he seems to move from a modest view to a bolder one. Whereas Taylor leaves open the possibility of such a superseding theory in 'Ethics and Ontology' by concluding that the 'hoped-for-reconciliation' between moral phenomenology and naturalist ontology is 'somewhat premature', ${ }^{63}$ he now suggests that the studies of physical and human nature invoke incompatible ontological realities:

We may also be seeing signs of a need for two independent accounts of reality, one describing those aspects of nature as it is in itself revealed to detached observers, and another account of reality as it is revealed to involved human beings. ${ }^{64}$

Taylor then comes very close to Putnam's pragmatic pluralism when he adds that there might be 'a plurality of revealing perspectives on the world (nature, cosmos, universe?) ${ }^{65}$ However, whereas the young Taylor concludes that 'we are still perplexed when we try to understand the relations between what we talk about in one stratum and what we talk about in others', ${ }^{66}$ the later Taylor provides at least three possible solutions to this problem.

The first is to accept that rival accounts of reality are simply 'dealing with quite different questions,' that is, insofar as 'the answers to one don't impinge in any way on our theories about the other,' for example, 'as some people suggest is the case between the issues of natural science and those of religious faith' ${ }^{67} \mathrm{~A}$ second solution is that 'one approach might just supersede the other, showing it to be inadequate,' for example, 'as post-Galilean mechanics relegated Aristotle's theory of motion' ${ }^{68}$ The third, most radical solution is that 'one science might offer a general theory, of which the valid findings of the other could be construed as special cases,' for example, 'as Einstein's theory supersedes and includes Newton's laws of motion' ${ }^{69}$ However, when it comes to explaining human behavior, Taylor loses no time in rejecting the second and third options:

Scientists and philosophers have, after all, so far failed to reconcile mechanical theories of physical reality with the seemingly undeniable facts of free will, 
consciousness, and meaning. Convergence in all these cases would certainly be satisfying [...] but we have to leave open the possibility that there is no single privileged way nature works. ${ }^{70}$

This leaves Taylor only the first option of embracing a plurality of revealing perspectives on the human world, all of which may be true. That is, while the young Taylor already concedes that "we have ceased to say that some particular language is the "real" way to talk about things' ${ }^{71}$ the later Taylor takes this idea to its final conclusion by arguing that 'one has be a pluralist where essences are concerned ${ }^{72}$ For Taylor the plural realist, then, there is no uncertainty, contradiction, or puzzlement in the idea that there could in principle be many such irreducible and incompatible perspectives on the world.

Difficulties arise, however, when we note that this 'pluralistic robust realist' affirmation of "many languages each correctly describing a different aspect of reality" ${ }^{73}$ is in stark contrast to the more critical perspective developed in 'Ethics and Ontology'. As we have seen, that paper argues that naturalist ontology can be shown to be wrong on account of moral phenomenology. Here Taylor implicitly tends towards the 'superseding' way of salvaging our different languages of self-understanding at the expense of the more pluralistic option of accepting different ontologies. In other words, as a critic of naturalism, he presses the idea that one superior approach (in this case moral phenomenology) can be used to show the inadequacy of others (in this case naturalist ontology). Far from simply accepting the ontological gap between them, Taylor here demands from us that we either enrich our naturalist ontology or revise our moral phenomenology to solve the problem of their relationship. $^{74}$

Notwithstanding the exploratory manner in which Taylor presents his realism, his attack on naturalist ontology brings him closer to the idea of a superseding theory or even of an all-inclusive view than to the pluralist recognition of different perspectives. It should not surprise us, then, that Taylor's final message is not about embracing pluralism but that 'there remain deep differences in basic ontology' ${ }^{75}$ Unfortunately, this restates rather than dissolves the issue of what we are committed to ontologically by our ethical views.

\section{Conclusion}

These are then the main features of Putnam's and Taylor's post-analytic-continental metaphysics. (1) Putnam sees ontological considerations as neither necessary nor sufficient for ethical theory. (2) He criticizes both inflationary and deflationary modes of metaphysics, either for postulating abstract entities behind our language games (Platonism) or for pressing these diverse languages into the fixed molds of empirical science (naturalism). (3) Yet in pronouncing his obituary on Ontology, Putnam ultimately overplays his hand as he implicitly endorses, rather than overcomes, metaphysical thinking in developing his pragmatic pluralism. (4) Taylor, on the other hand, sees ontological considerations as vitally important for understanding Ethics (broadly defined), but struggles until the very end of his career to clarify their meaning. (5) His tentative investigations culminate in the problem of what 
ontology can underpin our moral experience, and ultimately result in a strong incentive to revise naturalist ontology in favor of moral phenomenology. (6) Yet this last move is in clear tension with Taylor's pluralist realism that explicitly aims to leave open the possibility of multiple correct descriptions of the world.

To give the full stretch of Putnam's and Taylor's arguments the treatment they deserve lies beyond the scope of this paper. This much, however, seems clear: Putnam's unusual development from the view that 'humanly speaking' objectivity provides us with 'objectivity enough ${ }^{76}$ to the pronouncement of an obituary on all ontologizing is definitely worth confronting with Taylor's distinctive ontological perspective. Intriguingly, it would seem that the problems pressing on their accounts are direct opposites: whereas it remains unclear how Taylor can sustain his ontological view without contradicting his pluralistic realism, Putnam's problem is precisely how he can reject ontology without engaging in ontologizing himself. Yet is clear, at least, that the issues at stake here are metaphysical more than anything else.

For Taylor, reason in this domain cannot but be 'hermeneutical' since there are no 'knockdown arguments' in making sense of human action. ${ }^{77}$ In fact, this is precisely what makes ethical and ontological questions amendable to hermeneutical inquiry. As we have seen, the thrust of Taylor's hermeneutical argument is (just as in the original context of textual interpretation) to clarify a particular feature of our action - in this case moral experience - within the presumed overall meaning of the whole - in this case the broader ontological context within which our actions take place. In a word, his attempt is to use the sense of the part to make sense of the whole. As Taylor's attack on naturalism makes plain, this hermeneutical tactic ultimately consists in the phenomenological clarification of moral experience for the ontological purpose of examining the metaphysical background of our values.

Although Taylor's view is bound to disappointment those seeking clear-cut solutions, he nonetheless manages to raise the important question whether we understand fully the meaning of 'the whole', that is, the meaning of the ontological framework that makes our actions understandable. Yet even if Taylor argues that our experience as moral agents should lead us to correct the implicit naturalist ontology in our self-understanding, as a hermeneutist, he has no problem in acknowledging that it is perfectly possible to argue in the other direction as well. As Taylor explains, the challenge of the notorious 'hermeneutical circle' is precisely to balance potential arguments in both directions into an equilibrium in which one makes 'maximum sense' of the issues involved ${ }^{78}$ The upshot of this method is - in the ethical domain as much as the ontological - that we are in need of felicitous descriptions:

We explain properly, we make sense of the action/response, when we add to, or complexify, the range of meanings or motivations actually operating here. We have to enrich our comprehension of the landscapes of meaning that these agents act within. ${ }^{79}$

If we now return to the 'three-cornered' battle between naturalists, hermeneutists, and pragmatists with which we began, we can see that the role of hermeneutical argument within this discussion is to point out elements that rival views cannot account for. However, the debate gets more obscure when considering the peculiar contribution of naturalistic voices, 
namely, that they boldly exclude other explanatory languages by accepting only the terms of empirical science for explaining human action. Putnam makes a point like this when he says that 'the worst thing about the fact/value dichotomy is that in practice it functions as a discussion-stopper, and not just a discussion-stopper, but a thought-stopper' ${ }^{80}$ Recalling the hermeneutical condition that whatever meaning we recognize in ethics has to make sense within a larger ontological picture, Putnam's point is spot on: any monotheistic talk of the one real language stifles rather than encourages further debate and understanding.

This leaves us with the debate between hermeneutists and pragmatists, which definitely deserves further investigation. We can ask, for example, whether Putnam's rejection of Ontology can still accept Taylor's model of hermeneutical reasoning, and his closely related understanding of Ethics in the broad sense. Is there perhaps some space left within pragmatic pluralism for ontological truths that are neither inflationary nor deflationary? That is, could Putnam include in his method the step towards what might be called a 'pragmatic metaphysics', which rejects only Ontology, not ontology? But even where the differences between them are irreconcilable, we can still learn from Putnam and Taylor that when it comes to understanding morality we require neither causal scientific explanations nor pseudo-scientific naturalist ones but the development of a distinctive philosophical platform from which to investigate the complex relationship between ethics and ontology. Although I have been focusing here only on the ground prepared by Putnam and Taylor, there are doubtless many other ways of achieving this end.

\section{Bibliography}

Blackburn, Simon. Ruling Passions: A Theory of Practical Reasoning. Oxford: Clarendon Press, 1998.

Copp, David. 2006. The Ontology of Putnam's Ethics without Ontology.' Contemporary Pragmatism 3 (2) (2006): 39-53.

Critchley, Simon. Continental Philosophy: A Very Short Introduction. Oxford: Oxford University Press, 2001.

Heinämaa, Sara. 'Hermeneutics and the Analytic-Continental Divide.' In The Blackwell Companion to Hermeneutics, edited by Niall Keane and Chris Lawn, 573-584. Hoboken: Wiley-Blackwell, 2016.

Kitcher, Philip. 'The Naturalists Return.' Philosophical Review 101 (1) (1992): 53-114.

Peirce, Charles Sanders. The Collected Papers of Charles Sanders Peirce. Edited by Charles Harsthorne, Paul Weiss and Arthur Burks. 8 vols. Cambridge: Harvard University Press, 1931-1958. 
Philström, Sami. 'Putnam's Conception of Ontology.' Contemporary Pragmatism 3 (2) (2006): 1-13.

Putnam, Hilary. Reason, Truth and History. Cambridge: Cambridge University Press, 1981.

Putnam, Hilary. The Collapse of the Fact/Value Distinction. Cambridge: Harvard University Press, 2002.

Putnam, Hilary. 'The Content and Appeal of 'Naturalism'.' In Naturalism in Question, edited by Mario de Caro and David Macarthur, 59-70. Cambridge: Harvard University Press, 2004a.

Putnam, Hilary. Ethics Without Ontology. Cambridge: Harvard University Press, 2004b.

Putnam, Hilary. 'Replies to Commentators.' Contemporary Pragmatism 3 (2) (2006): 67-98.

Snow, Charles Percy. The Two Cultures. Cambridge: Cambridge University Press, 1959. Reprint, 1998.

Stroud, Barry. 'The Charm of Naturalism.' Proceedings and Address of the American Philosophical Society 70 (1996): 43-55.

Taylor, Charles. 'Ontology.' Philosophy 34 (1959): 125-141.

Taylor, Charles. The Explanation of Behaviour. London: Routledge and Kegan Paul, 1964.

Taylor, Charles. 'A Most Peculiar Institution.' In World, Mind, and Ethics. Essays on the Ethical Philosophy of Bernard Williams, edited by J. Altham and R. Harrison, 132-155. Cambridge: Cambridge University Press, 1995.

Taylor, Charles. 'Ethics and Ontology.' The Journal of Philosophy 100 (6) (2003): 305-320.

Taylor, Charles. The Language Animal: The Full Shape of the Human Linguistic Capacity. Cambridge: The Belknap Press of Harvard University Press, 2016.

Taylor, Charles (with Dreyfus, Hubert). Retrieving Realism. Cambridge, Massachusetts: Harvard University Press, 2015.

Tiercelin, Claudine. 'Metaphysics without Ontology?' Contemporary Pragmatism 3 (2) (2006): 55-66.

\section{About the Author}


Michiel Meijer is a postdoctoral researcher of the Research Foundation - Flanders (FWO) in the Department of Philosophy at the University of Antwerp. He is the author of Charles Taylor's Doctrine of Strong Evaluation (Rowman \& Littlefield, 2017). Recent publications include 'A Phenomenological Approach With Ontological Implications? Charles Taylor and Maurice Mandelbaum on Explanation in Ethics,' Ethical Theory and Moral Practice, 2017 (https://doi.org/10.1007/s10677-017-9837-7), 'Human-Related, not Human-Controlled: Charles Taylor on Ethics and Ontology,' International Philosophical Quarterly, 57 (3) (2017): 267-85, 'Is Charles Taylor (Still) a Weak Ontologist?' Dialogue: Canadian Philosophical Review, 56 (1) (2017): 65-87, and 'Does Charles Taylor Have a Nietzsche Problem?' Constellations: An International Journal of Critical and Democratic Theory, 24 (3) (2017): 372-86.

\section{Notes}

${ }^{1}$ I use the terms 'metaphysics' and 'ontology', as well as 'morality' and 'ethics', interchangeably, following Putnam's and Taylor's use of these terms.

${ }^{2}$ Snow, The Two Cultures.

${ }^{3}$ Critchley, Continental Philosophy, preface.

${ }^{4}$ Heinämaa, 'Hermeneutics and the Analytic-Continental Divide,' 573.

${ }^{5}$ Putnam, Ethics Without Ontology.

${ }^{6}$ Taylor, 'Ontology'; 'Ethics and Ontology'.

${ }^{7}$ Taylor, Retrieving Realism.

${ }^{8}$ Putnam, 'Replies to Commentators,' 89.

${ }^{9}$ Putnam, Ethics Without Ontology, 2.

${ }^{10}$ Ibid., 3 .

${ }^{11}$ Taylor, The Language Animal, 212, 214, 217.

${ }^{12}$ Ibid., 217, 218.

${ }^{13}$ Blackburn, Ruling Passions, 49.

${ }^{14}$ Kitcher, 'The Naturalists Return'; Stroud, 'The Charm of Naturalism'.

${ }^{15}$ Putnam, Reason, Truth and History, 143 (original emphasis).

${ }^{16}$ Taylor, The Explanation of Behaviour, 3; “'A Most Peculiar Institution,' 137.

${ }^{17}$ Putnam, 'The Content and Appeal,' 60-61; Ethics Without Ontology, 16.

${ }^{18}$ Taylor, 'Ethics and Ontology,' 306.

${ }^{19}$ Putnam, Ethics Without Ontology, 3.

${ }^{20}$ Ibid., 4, 21-22.

${ }^{21}$ Ibid., 3 (original emphasis).

${ }^{22}$ Ibid., 22 (original emphasis).

${ }^{23}$ Putnam, The Collapse of the Fact/Value Distinction, 124.

${ }^{24}$ Putnam, Ethics Without Ontology, 17-22.

${ }^{25}$ Ibid., 18-19 (original emphases).

${ }^{26}$ Ibid., 19-20.

${ }^{27}$ Ibid., 21 .

${ }^{28}$ Ibid., 22. 
${ }^{29}$ Tiercelin, 'Metaphysics without Ontology?', 55 (italics mine).

${ }^{30}$ Putnam. Ethics Without Ontology, 81.

${ }^{31}$ Ibid., 85 (original emphasis).

${ }^{32}$ Ibid., 77 (original emphases).

${ }^{33}$ Ibid., 84 (original emphasis).

${ }^{34}$ Ibid., 82.

${ }^{35}$ Ibid., 84 (original emphases).

${ }^{36}$ Pihlström, 'Putnam's Conception of Ontology,' 8.

${ }^{37}$ Copp, 'The Ontology of Putnam's,' 47, 48.

${ }^{38}$ Tiercelin, 'Metaphysics without Ontology?', 56. The quotations are from The Collected Paper of Charles Sanders Peirce (1931-1958).

${ }^{39}$ Taylor, 'Ontology,' 128, 139.

${ }^{40}$ Taylor, Retrieving Realism, 154; The Language Animal, 212.

${ }^{41}$ Taylor, The Language Animal, 192, 195.

${ }^{42}$ Ibid., 192-193.

${ }^{43}$ Ibid., 201-215.

${ }^{44}$ Taylor, 'Ontology,' 128-129.

${ }^{45}$ Ibid., 126-128.

${ }^{46}$ Ibid., 128.

${ }^{47}$ Ibid., 136.

${ }^{48}$ Ibid., 138.

${ }^{49}$ Ibid., 137, 139.

${ }^{50}$ Ibid.

${ }^{51}$ Ibid., 141 (original emphasis).

${ }^{52}$ Taylor, 'Ethics and Ontology,' 306.

${ }^{53}$ Ibid., 319.

${ }^{54}$ Ibid., 308 (original emphasis).

${ }^{55}$ Ibid.

${ }^{56}$ Ibid., 308, 309.

${ }^{57}$ Ibid., 310.

${ }^{58}$ Ibid., 310, 312, 320.

${ }^{59}$ Ibid., 311.

${ }^{60}$ Ibid., 320.

${ }^{61}$ Taylor, Retrieving Realism, 108.

${ }^{62}$ Ibid., 158-159.

${ }^{63}$ Taylor, 'Ethics and Ontology,' 320.

${ }^{64}$ Taylor, Retrieving Realism, 153.

${ }^{65}$ Ibid., 154.

${ }^{66}$ Taylor, 'Ontology,' 139.

${ }^{67}$ Taylor, Retrieving Realism, 158.

${ }^{68}$ Ibid.

${ }^{69}$ Ibid.

${ }^{70}$ Ibid., 153. 
${ }^{71}$ Taylor, 'Ontology,' 139.

72 Taylor, Retrieving Realism, 153

${ }^{73}$ Ibid., 154 (original emphases).

${ }^{74}$ Taylor, 'Ethics and Ontology,' 310, 312.

${ }^{75}$ Taylor, Retrieving Realism, 167.

${ }^{76}$ Putnam, Reason, Truth and History, 168.

${ }^{77}$ Taylor, The Language Animal, 211, 217.

${ }^{78}$ Ibid., 218.

${ }^{79}$ Ibid., 217.

${ }^{80}$ Putnam, The Collapse of the Fact/Value Distinction, 44 (italics mine). 